\title{
Targeting the insulin-like growth factor-1 receptor in human cancer
}

\author{
Alexandre Arcaro* \\ Division of Pediatric Hematology/Oncology, Department of Clinical Research, University of Bern, Bern, Switzerland
}

\section{Edited by:}

Pierre Sonveaux, University of

Louvain Medical School, Belgium

\section{Reviewed by:}

Marc Poirot, Institut National de la

Santé et de la Recherche Médicale,

France

Jian Hui Wu, McGill University,

Canada

\section{${ }^{*}$ Correspondence:}

Alexandre Arcaro, Division of Pediatric Hematology/Oncology, Department of Clinical Research, University of Bern, Tiefenaustrasse 120c, CH-3004 Bern, Switzerland.

e-mail:alexandre.arcaro@dkf.unibe.ch
The insulin-like growth factor (IGF) signaling system plays a crucial role in human cancer and the IGF-1 receptor (IGF-1R) is an attractive drug target against which a variety of novel anti-tumor agents are being developed. Deregulation of the IGF signaling pathway frequently occurs in human cancer and involves the establishment of autocrine loops comprising IGF-1 or IGF-2 and/or IGF-1R over-expression. Epidemiologic studies have documented a link between elevated IGF levels and the development of solid tumors, such as breast, colon, and prostate cancer. Anti-cancer strategies targeting the IGF signaling system involve two main approaches, namely neutralizing antibodies and small molecule inhibitors of the IGF-1R kinase activity. There are numerous reports describing anti-tumor activity of these agents in pre-clinical models of major human cancers. In addition, multiple clinical trials have started to evaluate the safety and efficacy of selected IGF-1R inhibitors, in combination with standard chemotherapeutic regimens or other targeted agents in cancer patients. In this mini review, I will discuss the role of the IGF signaling system in human cancer and the main strategies which have been so far evaluated to target the IGF-1R.

Keywords: cancer, clinical trials, insulin-like growth factor, IGF-1 receptor, monoclonal antibody, tyrosine kinase inhibitor

\section{THE IGF/INSULIN FAMILY OF GROWTH FACTORS}

The insulin-like growth factor (IGF)/insulin family of growth factors is an evolutionally conserved system which plays a crucial role in the growth and development of many tissues and the regulation of overall growth and metabolism. This system comprises three receptors [insulin receptor (IR), IGF-1 receptor (IGF-1R), and IGF-2/mannose 6-phosphate receptor (M-6-PR)], three ligands (insulin, IGF-1, and IGF-2), and six known types of circulating IGF-binding proteins (IGFBP1-6; Pollak et al., 2004; Pollak, 2008). The IGF-1R is a receptor tyrosine kinase which is widely expressed in many human tissues and cell types and is highly homologous to the IR. However, these two receptors have distinct functions, since the IGF-1R controls apoptosis, cell growth, and differentiation, while the IR regulates physiological processes. The IGF-1R is a heterotetrameric glycoprotein composed of two $\alpha$ and two $\beta$ subunits, post-transcriptionally linked by disulfide bonds. Activation of the IGF-1R is achieved by binding of its specific ligand to the extracellular $\alpha$ subunits, which leads to autophosphorylation of three tyrosine residues within the kinase domain of the IGF-1R $\beta$ subunit.

Insulin-like growth factors 1 and 2 are single-chain polypeptides with a high sequence homology to pro-insulin. The half-lives, transportation, and bioavailability of the IGFs circulating at high concentrations in the bloodstream and extracellular fluids are modulated by several high affinity IGF-binding proteins (IGFBP16). More than $99 \%$ of the circulating IGFs are bound to IGFBPs and the IGFBPs themselves are tightly regulated by tissue specificity, cell or matrix association, phosphorylation, and proteolysis by various proteases (Baxter, 2000).

Both IGF-1 and IGF-2 interact with the IGF-1R, although IGF-1 shows a much higher affinity than IGF-2. The IGF-2 receptor
(M-6-PR), differs significantly from the IGF-1R and does not activate specific cellular responses. The ability of the highly homologous IGF-1R and IR to form hybrid receptors by dimerization further increases the complexity of the signaling system. Such IGF-1R/IR hybrid receptors have been reported to influence cell responses by altering the affinities of their growth factor ligands (Pandini etal., 2002; Pollak, 2008; Gallagher and LeRoith, 2010). These hybrid receptors can stimulate cell proliferation, especially in the case of the IR-A isoform, which has been found over-expressed in cancer (Denley et al., 2003).

The main intracellular signaling pathways downstream of the IGF-1R use the IR substrates- 1 to -4 (IRS-1 to -4 ) and the Src-homology collagen protein (Shc) isoforms as adapter molecules. Phosphorylation of the IRS adapter molecules on one hand triggers activation of the phosphoinositide 3-kinase (PI3K)/Akt signaling pathway, whereas, on the other hand, the Shc adapter activates signaling by the Ras/Raf/MEK/Erk signaling pathway (Figure 1). Generally, signals controlled by the IGF-1R have pleiotropic effects on cell behavior controlling cell proliferation, differentiation, and cell migration, but also regulating the apoptotic machinery (Pollak, 2008; Gallagher and LeRoith, 2010).

\section{THE ROLE OF THE IGF-1R IN HUMAN CANCER}

In the past decades, a large body of evidence has arisen, supporting a key role for IGF-1R signaling in various types of human cancers (Pollak, 2008; Gallagher and LeRoith, 2010). A number of studies performed in the last two decades have demonstrated a role for this receptor in the transformation of cells, cancer cell proliferation, as well as in metastatic events (Kaleko et al., 1990; Sell et al., 1994; Scotlandi et al., 2002; Sachdev et al., 2004; Carboni et al., 2005). 


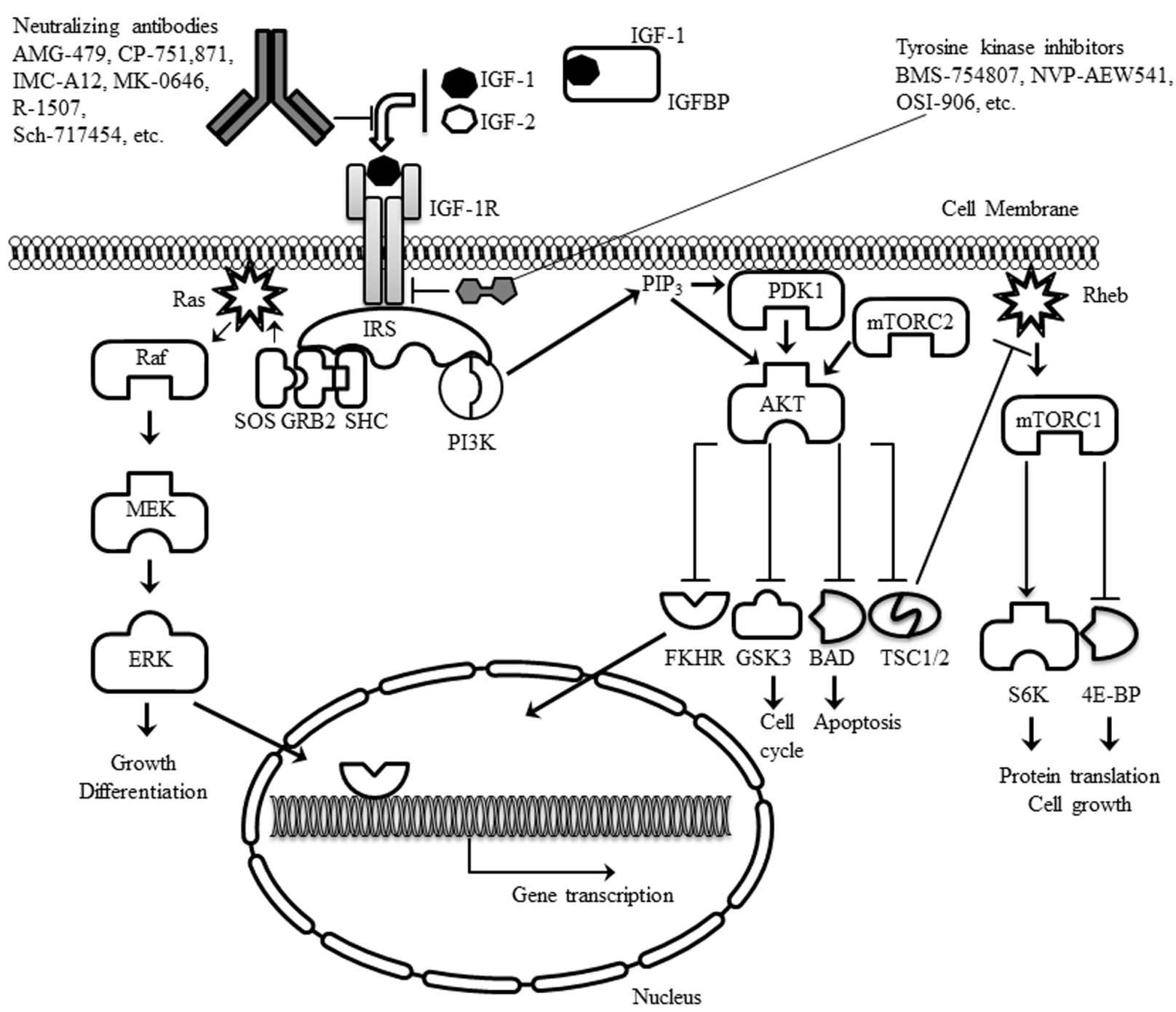

FIGURE 1 | Schematic representation of the IGF-1R, its ligands and the main intracellular signaling pathways activated. The two main classes of experimental drugs against the receptor (antibodies and tyrosine kinase inhibitors) are also depicted.

While no recurrent cancer-specific mutations of the IGF-1R or its ligands have been described to date, a plethora of studies have provided evidence for a link between this signaling pathway and the risk of developing cancer (Khandwala et al., 2000; Pollak, 2008; Gallagher and LeRoith, 2010). The most common findings associated with deregulated IGF signaling are over-expression of the IGF-1R or the establishment of autocrine or paracrine signaling loops. While high expression levels of the IGF-1R have been found in breast and colorectal cancer, autocrine signaling loops are more common, and have been reported in a wide variety of human malignancies. Paracrine signaling has mainly been described for breast cancer, where stromal cells have been shown to produce IGF-1 and IGF-2. Population studies have further highlighted the importance of IGF signaling in some of the most common cancers (Guerreiro et al., 2006a; Pollak, 2008; Gallagher and LeRoith, 2010). The published evidence from epidemiological studies has revealed a correlation between elevated IGF-1 levels and an increased risk of cancer diagnosis (Pollak et al., 2004; Guerreiro et al., 2006a; Pollak, 2008; Gallagher and LeRoith, 2010). Although the population studies did not always come to the same conclusions, systematic reviews of these results led to the interpretation that circulating IGF-1 levels are indeed related to a risk of several common cancers (Renehan et al., 2004). The most significant correlation between increased levels of IGF-1 and the risk of cancer diagnosis was found for prostate cancer, pre-menopausal breast cancer, and colorectal cancer (Wolk et al., 1998; Ma etal., 1999; Giovannucci et al., 2000; Harman et al., 2000; Kaaks etal., 2000; Stattin et al., 2000; Chan et al., 2002; Palmqvist et al., 2002; Chen et al., 2009; Major et al., 2010; Rinaldi et al., 2010). However, it should be noted that no significant overall associations were found between breast cancer and common germline variation in IGF1 and other genes involved in IGF-1 metabolism in a large, comprehensive study (Canzian et al., 2010). 
In summary, mechanistic and epidemiological studies have provided substantial information supporting a role for IGF signaling and the IGF-1R in human cancers. The IGF-1R has emerged as a promising target for the development of new therapeutic approaches, which can be combined with other classical treatment regimens.

\section{STRATEGIES TO TARGET THE IGF-1R IN CANCER THERAPY}

The IGF-1R can be inhibited through various experimental approaches (Figure 1). I will focus the discussion on the two approaches which are currently being evaluated in clinical trials: (A) neutralizing antibodies and (B) small molecule inhibitors of the IGF-1R tyrosine kinase activity.

\section{NEUTRALIZING ANTIBODIES}

A number of monoclonal antibodies have been developed to target the receptor itself, which bind to the extracellular domains of the IGF-1R and block ligand binding. A feature common to all anti-IGF-1R antibodies, probably more important than the blocking activity itself, is their ability to down-regulate of the IGF-1R overtime by promoting internalization of the receptor. Receptortargeting antibodies might have important therapeutic advantages, concerning both specificity and toxicity. A variety of fully human anti-IGF-1R monoclonal antibodies have been characterized and showed strong anti-tumor activity in vitro and in vivo (King and Wong, 2012). Most IGF-1R antibodies which have been evaluated in clinical trials so far have proven to be well tolerated (King and Wong, 2012). A selection of the results published with these molecules is described below.

AMG-479 (ganitumab; Amgen) is a fully human immunoglobulin G1 (IgG1) against the IGF-1R (Beltran et al., 2009). AMG-479 blocks IGF-1 and IGF-2 binding to the IGF-1R without crossreacting with the IR and also inhibits the activation of IGF-1R homodimers and IGF-1R/IR hybrids (Beltran et al., 2009). A phase I study in patients with advanced solid malignancies or non-Hodgkin's lymphoma showed that AMG 479 can be administered safely and tumor responses were observed in patients with Ewing/primitive neuroectodermal tumors and neuroendocrine tumors (Tolcher etal., 2009). The efficacy and safety of ganitumab combined with gemcitabine was investigated in a randomized phase II trial in patients with metastatic pancreatic cancer (Kindler et al., 2012). The combination had tolerable toxicity and showed trends toward improved survival rate and overall survival (Kindler etal., 2012). Another phase II study with ganitumab as a monotherapy in patients with metastatic Ewing family tumors or desmoplastic small round cell tumors showed that it was well tolerated and demonstrated activity in both tumor types (Tap et al., 2012). Several other phase II clinical trials evaluating ganitumab, alone and in combination with other anticancer agents, are ongoing in patients with various types of solid tumors.

CP-751,871 (figitumumab; Pfizer) is a fully human IgG2 antibody which blocks binding of IGF-1 to its receptor, IGF-1-induced receptor autophosphorylation and induces the down-regulation of IGF-1R (Cohen et al., 2005; Gualberto, 2010). A phase I study in patients with refractory solid tumors showed that figitumumab has a favorable safety profile and is well tolerated (Haluska et al., 2007).
A phase I study in patients with multiple myeloma confirmed the favorable profile of this agent and some responses were reported in patients treated with figitumumab in combination with dexamethasone (Lacy et al., 2008). Another phase I study in patients with sarcoma and Ewing's sarcoma found figitumumab to be well tolerated and had anti-tumor activity in Ewing's sarcoma (Olmos et al., 2010). A phase Ib study tested figitumumab in combination with docetaxel in patients with advanced solid tumors and found this regimen to be well tolerated (Molife et al., 2010). A phase I trial of the combination of everolimus and figitumumab was conducted in patients with advanced sarcomas and other solid tumors (Quek et al., 2011). The combination appeared safe and exhibited interesting anti-tumor activity warranting further investigation (Quek et al., 2011). In squamous cell carcinoma of the head and neck, figitumumab showed no activity in a phase II trial as a single agent (Schmitz et al., 2012). Although figitumumab induced a downregulation of the IGF-1R, an activation of the epidermal growth factor receptor (EGFR) pathway was noted (Schmitz et al., 2012), which may contribute to resistance to this agent. Despite these results, two large-phase III trials investigating the addition of figitumumab to either carboplatin/paclitaxel (NCT00596830), or to erlotinib (NCT00673049) in advanced non-small cell lung cancer (NSCLC) patients were terminated after planned interim analysis indicated futility.

IMC-A12 (cixutumumab; ImClone Systems Incorporated) is a fully human monoclonal anti-IGF-1R IgG1 antibody, which inhibits receptor activation, downstream signaling and also mediates internalization and degradation of the receptor (Rowinsky et al., 2007). Although promising single-agent activity was observed, the most impressive effects of targeting the IGF-1R with IMC-A12 were observed when this agent was combined with cytotoxic agents or other targeted therapeutics (Rowinsky et al., 2007). The results of a phase II study of IMC-A12, with or without cetuximab, in patients with refractory metastatic colorectal cancer documented that IMC-A12 alone, or in combination with cetuximab, was insufficient to warrant additional study in patients with colorectal cancer refractory to EGFR inhibitors (Reidy et al., 2010). IMC-A12 was evaluated in combination with the mammalian target of rapamycin (mTOR) inhibitor temsirolimus in patients with refractory Ewing's sarcoma family tumors (Naing et al., 2012). The combination was well tolerated and showed preliminary evidence of durable anti-tumor activity (Naing et al., 2012). Currently several clinical trials are evaluating IMC-A12 as a single agent or in combination with standard chemotherapy or other targeted agents.

MK-0646 (dalotuzumab, h7C10; Merck) is a humanized IgG1 monoclonal antibody against the IGF-1R (Goetsch et al., 2005; Scartozzi et al., 2010). Pre-clinical studies have demonstrated that dalotuzumab acts by inhibiting IGF-1- and IGF-2-mediated tumor cell proliferation (Goetsch et al., 2005), IGF-1R autophosphorylation, and Akt phosphorylation (Wan et al., 2007; Cao et al., 2008; Broussas et al., 2009; Scartozzi et al., 2010). Data from phase I clinical trials demonstrated that dalotuzumab is safe, well tolerated and significantly inhibits tumor proliferation (Scartozzi et al., 2010; Atzori et al., 2011). A phase II study evaluated the safety and efficacy of MK-0646, as monotherapy in patients with metastatic, well-differentiated neuroendocrine tumors (Reidy-Lagunes et al., 
2012). MK-0646 was inactive as a single agent and thus further studies of MK-0646 as a monotherapy in unselected neuroendocrine tumors are not warranted (Reidy-Lagunes et al., 2012). Several clinical trials evaluating dalotuzumab, alone and in combination with other anti-cancer agents, are ongoing in patients with various types of solid tumors and in patients with multiple myeloma.

R-1507 (robatumumab, Roche) is a fully humanized anti-IGF1R monoclonal antibody. In a panel of NSCLC cell lines predictive biomarkers of response to R-1507 were investigated. While levels of phospho-IGF-1R did not correlate with drug sensitivity, the sensitive NSCLC cell lines displayed high levels of total IGF-1R and higher copy numbers (Gong et al., 2009). Different studies reported on the enhanced efficacy of R-1507 in combination with chemotherapy or other targeted agents in several tumors (Gong et al., 2009; Kolb et al., 2010; Wojtalla et al., 2012). In a phase I study of R-1507 in patients with advanced solid tumors R1507 was well tolerated and showed anti-tumor activity in patients with solid neoplasms, in particular Ewing's sarcoma (Kurzrock et al., 2010). In a phase II study in patients with recurrent or refractory Ewing's sarcoma, R-1507 induced partial/complete responses in only a subgroup of patients (Pappo et al., 2011). A phase II study of R-1507 in combination with erlotinib was also conducted in advanced-stage NSCLC. The combination did not provide any benefit in comparison to erlotinib alone in unselected NSCLC patients (Ramalingam et al., 2011). Several clinical trials evaluating R-1507, as single agent or in combination with other drugs, are ongoing in patients with various types of solid tumors.

Sch-717454 (19D12; Schering-Plough) is a humanized IgG1 anti-IGF-1R antibody which inhibits IGF binding and autophosphorylation of both IGF-1R/IGF-1R homodimers and IGF-1R/IR heterodimers (but not IR homodimers; Wang et al., 2005). There are no published results from clinical trials with Sch-717454 so far. Four clinical trials have been performed with Sch-717454, one of which is ongoing, one was completed and two terminated.

\section{SMALL MOLECULE INHIBITORS OF THE IGF-1R TYROSINE KINASE ACTIVITY}

Several compounds with selectivity toward the IGF-1R tyrosine kinase have entered clinical trials (King and Wong, 2012). Advances in characterization of the structural biology of the insulin and IGF-1R were of great importance for the design of specific IGF-1R inhibitors (De Meyts and Whittaker, 2002). IGF$1 \mathrm{R}$ kinase inhibitors are likely candidates to become anti-IGF-1R drugs. However, concerns regarding cross-reactivity with the IR and toxicity, as well as possible mechanisms of resistance still ought to be carefully addressed. A selection of results with small molecule IGF-1R tyrosine kinase inhibitors (Figure 2) in pre-clinical models is presented below.

BMS-754807 (Bristol-Myers Squibb) is a potent and reversible inhibitor of the IGF-1R/IR family kinases (Carboni et al., 2009; Wittman etal., 2009). BMS-754807 effectively inhibited the growth of a broad range of human tumor types in vitro and was active in multiple xenograft tumor models (Carboni et al., 2009). Combination studies with BMS-754807 revealed synergies when the drug was combined with cytotoxic, hormonal, and targeted agents (Carboni etal., 2009). In triple-negative breast cancers BMS-754807 treatment resulted in tumor regression when combined with docetaxel (Litzenburger et al., 2011). BMS-754807 was tested by the Pediatric Preclinical Testing Program and in vivo activity was most commonly observed in the neuroblastoma and rhabdomyosarcoma panels (Kolb et al., 2011). In a subsequent study, a BMS-754807-resistant rhabdomyosarcoma cell line model was developed, which revealed that the platelet-derived growth factor receptor alpha (PDGFR $\alpha$ ) plays a role in acquired resistance to BMS-754807. There are now several clinical trials (phase I and II) ongoing with BMS-754807.

NVP-ADW742 and NVP-AEW541 (Novartis) are small molecular weight kinase inhibitors of the IGF-1R, which are specific for the IGF-1R at the cellular level (Garcia-Echeverria et al., 2004; Mitsiades et al., 2004). NVP-ADW742 and NVP-AEW541 have been extensively used in pre-clinical studies in a broad range of human cancer models. However, these compounds were not considered further for clinical development because of toxicity problems observed during the pre-clinical testing phase. The potential of NVP-ADW742 and NVP-AEW541 as single agents or in combination with chemotherapeutic drugs human was investigated in acute myeloid leukemia, Ewing's sarcoma, medulloblastoma, neuroblastoma, and small cell lung cancer (Scotlandi et al., 2005; Warshamana-Greene et al., 2005; Guerreiro et al., 2006b; Tanno et al., 2006; Doepfner et al., 2007; Tazzari et al., 2007; Urbanska et al., 2007). In atypical teratoid/rhabdoid tumor cells of the central nervous system, NVP-AEW541 was shown to inhibit cell proliferation and survival by blocking IGF-1R and IR activation by autocrine loops involving IGFs and insulin (Arcaro et al., 2007). In colorectal cancer, studies with NVP-AEW541 suggested that a combination therapy targeting both EGFR and IGF-1R could be a promising approach (Kaulfuss et al., 2009). A study in rhabdomyosarcoma also underscored the therapeutic potential of simultaneous targeting of IGF-1R and human epidermal growth factor receptor 2 (HER2) to abrogate resistance (Abraham et al., 2011). In pediatric glioblastoma co-treatment of the PDGFR inhibitor imatinib with NVP-AEW541 resulted in a highly synergistic interaction in vitro and increased efficacy in vivo (Bielen et al., 2011).

OSI-906 (Astellas Pharma) is a potent, selective, and orally bioavailable dual IGF-1R/IR kinase inhibitor which has demonstrated in vivo efficacy in tumor models and is currently in clinical testing (Mulvihill et al., 2009). The activity of OSI-906 in combination with standard chemotherapies was documented in colorectal cancer models (Flanigan et al., 2010). Simultaneous administration of OSI-906 and doxorubicin also significantly enhanced the anti-tumor effect of doxorubicin (Zeng et al., 2012). In human tumor cells co-expressing IGF-1R and IR, it was reported that co-targeting IGF-1R and IR with OSI-906 provides superior antitumor efficacy compared with targeting IGF-1R alone using a neutralizing antibody (Buck et al., 2010). Another study described predictive biomarkers for OSI-906 in colorectal cancer (Pitts et al., 2010). Baseline gene expression data from cell lines and xenografts, in combination with IGF-1R detection by in situ hybridization and KRAS mutational status, was able to accurately predict OSI-906 sensitivity (Pitts et al., 2010). There are now several clinical trials (phase I and II) ongoing with OSI-906. 
<smiles>C[C@]1(C(=O)Nc2ccc(F)nc2)CCCN1c1nc(Nc2cc(C3CC3)[nH]n2)c2cccn2n1</smiles>

BMS-754807

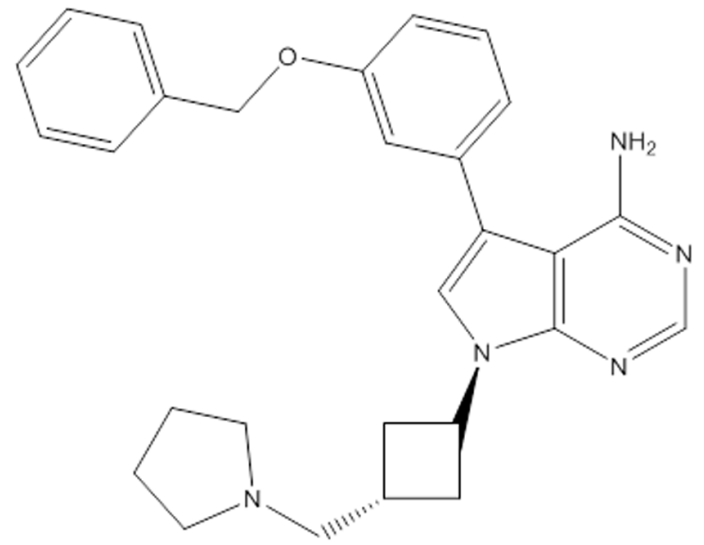

NVP-ADW742

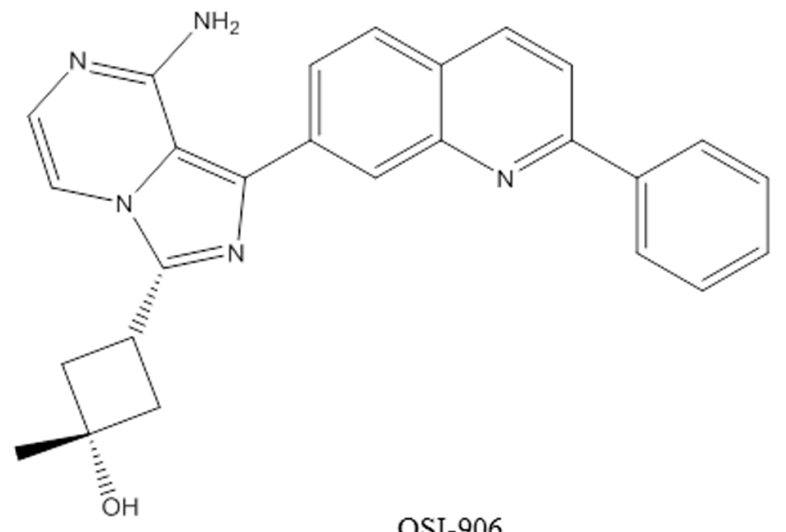

OSI-906

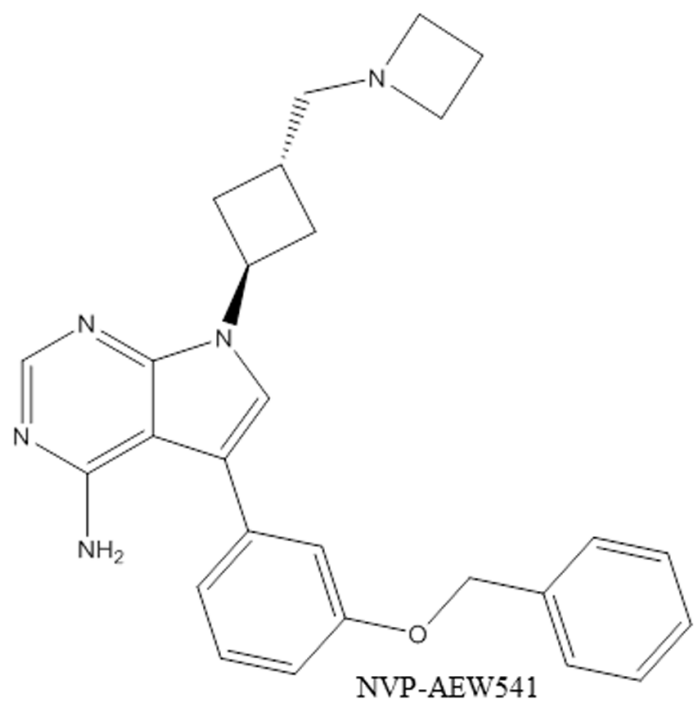

FIGURE 2 | Chemical structures of the IGF-1R tyrosine kinase inhibitors discussed in this article.

\section{CONCLUSION}

The available data from the first clinical trials with agents targeting the IGF-1R have been positive enough to launch several phase II and III trials in various human cancers. The IGF-1R antibodies appear to have a favorable safety profile and have been demonstrated to reduce IGF-1R signaling in patients. Concerning the IGF-1R tyrosine kinase inhibitors, the first published data from clinical trials are still awaited. There have been several cases of responses in phase I and II trials with anti-IGF-1R antibodies, but these agents will most likely not be useful in unselected patient populations. In addition, some phase II and III trials have been suspended or terminated, because of lack of efficacy of the antibodies (such as figitumumab in NSCLC). The identification of predictive biomarkers is of crucial importance for the further development of anti-cancer therapies based on anti-IGF-1R

\section{REFERENCES}

Abraham, J., Prajapati, S. I., Nishijo,

K., Schaffer, B. S., Taniguchi,

E., Kilcoyne, A., et al. (2011).

Evasion mechanisms to Igf1r

inhibition in rhabdomyosarcoma.
Mol. Cancer Ther. 10 697-707.

Arcaro, A., Doepfner, K. T., Boller, D., Guerreiro, A. S., Shalaby, T., Jackson, S. P., et al. (2007). Novel role for insulin as an autocrine growth

agents (King and Wong, 2012). In conclusion, there are multiple challenges still ahead, including the multiplicity of potential cancer indications and drug combinations, as well as the need of biomarkers for resistance and sensitivity.

\section{ACKNOWLEDGMENTS}

Work in the author's laboratory is supported by grants from the European Community FP7 (ASSET, project number: 259348 and LUNGTARGET, project number: 259770), the Swiss National Science Foundation (Grant 31003A-120294), the Fondation FORCE, the Novartis Stiftung für Medizinisch-Biologische Forschung, the Jubiläumsstiftung der Schweizerischen Mobiliar Genossenschaft, the Stiftung zur Krebsbekämpfung, the Huggenberger-Bischoff Stiftung zur Krebsforschung, the UniBern Forschungsstiftung, and the Stiftung für klinisch-experimentelle Tumorforschung, Bern.

factor for malignant brain tumour cells. Biochem. J. 406, 57-66.

Atzori, F., Tabernero, J., Cervantes, A., Prudkin, L., Andreu, J., Rodriguez-Braun, E., et al. (2011). A phase I, pharmacokinetic and pharmacodynamic study of dalotuzumab (MK-0646), an antiIGF-1R monoclonal antibody, in patients with advanced solid tumors. Clin. Cancer Res. 17, 63046312. 
Baxter, R. C. (2000). Insulin-like growth factor (IGF)-binding proteins: interactions with IGFs and intrinsic bioactivities. Am. J. Physiol. Endocrinol. Metab. 278, E967-E976.

Beltran, P. J., Mitchell, P., Chung, Y. A., Cajulis, E., Lu, J., Belmontes, B., et al. (2009). AMG 479, a fully human antiinsulin-like growth factor receptor type I monoclonal antibody, inhibits the growth and survival of pancreatic carcinoma cells. Mol. Cancer Ther. 8 , 1095-1105.

Bielen, A., Perryman, L., Box, G. M., Valenti, M., De Haven Brandon, A., Martins, V., et al. (2011). Enhanced efficacy of IGF1R inhibition in pediatric glioblastoma by combinatorial targeting of PDGFR $\alpha / \beta$. Mol. Cancer Ther. 10, 1407-1418.

Broussas, M., Dupont, J., Gonzalez, A., Blaecke, A., Fournier, M., Corvaia, N., et al. (2009). Molecular mechanisms involved in activity of h7C10, a humanized monoclonal antibody, to IGF-1 receptor. Int. J. Cancer 124, 2281-2293.

Buck, E., Gokhale, P. C., Koujak, S., Brown, E., Eyzaguirre, A., Tao, N., et al. (2010). Compensatory insulin receptor (IR) activation on inhibition of insulin-like growth factor1 receptor (IGF-1R): rationale for cotargeting IGF-1R and IR in cancer. Mol. Cancer Ther. 9, 26522664.

Canzian, F., Cox, D. G., Setiawan, V. W., Stram, D. O., Ziegler, R. G., Dossus, L., et al. (2010). Comprehensive analysis of common genetic variation in 61 genes related to steroid hormone and insulin-like growth factorI metabolism and breast cancer risk in the NCI breast and prostate cancer cohort consortium. Hum. Mol. Genet. 19, 3873-3884.

Cao, L., Yu, Y., Darko, I., Currier, D., Mayeenuddin, L. H., Wan, X., et al. (2008). Addiction to elevated insulin-like growth factor I receptor and initial modulation of the AKT pathway define the responsiveness of rhabdomyosarcoma to the targeting antibody. Cancer Res. 68, 80398048.

Carboni, J. M., Lee, A. V., Hadsell, D. L., Rowley, B. R., Lee, F. Y., Bol, D. K., et al. (2005). Tumor development by transgenic expression of a constitutively active insulin-like growth factor I receptor. Cancer Res. 65, 37813787.

Carboni, J. M., Wittman, M., Yang, Z., Lee, F., Greer, A., Hurlburt, W., et al. (2009). BMS-754807, a small molecule inhibitor of insulinlike growth factor-1R/IR. Mol. Cancer Ther. 8, 3341-3349.
Chan, J. M., Stampfer, M. J., Ma, J., Gann, P., Gaziano, J. M., Pollak, M., et al. (2002). Insulin-like growth factor-I (IGF-I) and IGF binding protein-3 as predictors of advancedstage prostate cancer. J. Natl. Cancer Inst. 94, 1099-1106.

Chen, W., Wang, S., Tian, T., Bai, J., Hu, Z., Xu, Y., et al. (2009). Phenotypes and genotypes of insulin-like growth factor 1, IGF-binding protein-3 and cancer risk: evidence from 96 studies. Eur. J. Hum. Genet. 17, 1668 1675.

Cohen, B. D., Baker, D. A., Soderstrom, C., Tkalcevic, G., Rossi, A. M., Miller, P. E., et al. (2005). Combination therapy enhances the inhibition of tumor growth with the fully human anti-type 1 insulin-like growth factor receptor monoclonal antibody CP-751,871. Clin. Cancer Res. 11, 2063-2073.

De Meyts, P., and Whittaker, J. (2002). Structural biology of insulin and IGF1 receptors: implications for drug design. Nat. Rev. Drug Discov. 1, 769-783.

Denley, A., Wallace, J. C., Cosgrove, L. J., and Forbes, B. E. (2003). The insulin receptor isoform exon 11(IR-A) in cancer and other diseases: a review. Horm. Metab. Res. 35, 778-785.

Doepfner, K. T., Spertini, O., and Arcaro, A. (2007). Autocrine insulinlike growth factor-I signaling promotes growth and survival of human acute myeloid leukemia cells via the phosphoinositide 3-kinase/Akt pathway. Leukemia 21, 1921-1930.

Flanigan, S. A., Pitts, T. M., Eckhardt, S. G., Tentler, J. J., Tan, A. C., Thorburn, A., et al. (2010). The insulin-like growth factor I receptor/insulin receptor tyrosine kinase inhibitor PQIP exhibits enhanced antitumor effects in combination with chemotherapy against colorectal cancer models. Clin. Cancer Res. $16,5436-5446$

Gallagher, E. J., and LeRoith, D. (2010). The proliferating role of insulin and insulin-like growth factors in cancer. Trends Endocrinol. Metab. 21, 610-618.

Garcia-Echeverria, C., Pearson, M. A., Marti, A., Meyer, T., Mestan, J., Zimmermann, J., etal. (2004) In vivo antitumor activity of NVPAEW541-A novel, potent, and selective inhibitor of the IGF-IR kinase. Cancer Cell 5, 231-239.

Giovannucci, E., Pollak, M. N., Platz, E. A., Willett, W. C., Stampfer, M. J., Majeed, N., et al. (2000). A prospective study of plasma insulinlike growth factor-1 and binding protein-3 and risk of colorectal neoplasia in women. Cancer Epidemiol. Biomarkers Prev. 9, 345-349.

Goetsch, L., Gonzalez, A., Leger, O., Beck, A., Pauwels, P. J., Haeuw, J. F., etal. (2005). A recombinant humanized anti-insulin-like growth factor receptor type I antibody (h7C10) enhances the antitumor activity of vinorelbine and anti-epidermal growth factor receptor therapy against human cancer xenografts. Int. J. Cancer 113 316-328.

Gong, Y., Yao, E., Shen, R., Goel, A., Arcila, M., Teruya-Feldstein, J., et al. (2009). High expression levels of total IGF-1R and sensitivity of NSCLC cells in vitro to an anti-IGF-1R antibody (R1507). PLoS ONE 4:e7273. doi: 10.1371/journal.pone.0007273

Gualberto, A. (2010). Figitumumab (CP-751,871) for cancer therapy. Expert Opin. Biol. Ther. 10 575-585.

Guerreiro, A. S., Boller, D., Doepfner, K. T., and Arcaro, A. (2006a). IGF-IR: potential role in antitumor agents. Drug News Perspect. 19, 261-272.

Guerreiro, A. S., Boller, D., Shalaby, T., Grotzer, M. A., and Arcaro, A. (2006b). Protein kinase B modulates the sensitivity of human neuroblastoma cells to insulin-like growth factor receptor inhibition. Int. J. Cancer 119, 2527-2538.

Haluska, P., Shaw, H. M., Batzel, G. N., Yin, D., Molina, J. R., Molife, L. R., et al. (2007). Phase I dose escalation study of the anti insulin-like growth factor-I receptor monoclonal antibody CP-751,871 in patients with refractory solid tumors. Clin. Cancer Res. 13, 5834-5840.

Harman, S. M., Metter, E. J., Blackman, M. R., Landis, P. K., and Carter, H. B. (2000). Serum levels of insulin-like growth factor I (IGF-I), IGF-II, IGF-binding protein-3, and prostate-specific antigen as predictors of clinical prostate cancer. $J$. Clin. Endocrinol. Metab. 85, 42584265.

Kaaks, R., Toniolo, P., Akhmedkhanov, A., Lukanova, A., Biessy, C. Dechaud, H., et al. (2000). Serum C-peptide, insulin-like growth factor (IGF)-I, IGF-binding proteins, and colorectal cancer risk in women. J. Natl. Cancer Inst. 92, 15921600.

Kaleko, M., Rutter, W. J., and Miller, A. D. (1990). Overexpression of the human insulinlike growth factor I receptor promotes ligand-dependent neoplastic transformation. Mol. Cell. Biol. 10, 464-473.
Kaulfuss, S., Burfeind, P., Gaedcke, J., and Scharf, J. G. (2009). Dual silencing of insulin-like growth factor-I receptor and epidermal growth factor receptor in colorectal cancer cells is associated with decreased proliferation and enhanced apoptosis. Mol. Cancer Ther. 8, 821-833.

Khandwala, H. M., Mccutcheon, I. E., Flyvbjerg, A., and Friend, K. E. (2000). The effects of insulin-like growth factors on tumorigenesis and neoplastic growth. Endocr. Rev. 21, 215-244.

Kindler, H. L., Richards, D. A., Garbo, L. E., Garon, E. B., Stephenson, J. J. Jr., Rocha-Lima, C. M., et al. (2012). A randomized, placebo-controlled phase 2 study of ganitumab (AMG 479) or conatumumab (AMG 655) in combination with gemcitabine in patients with metastatic pancreatic cancer. Ann. Oncol. 23, 2834-2842.

King, E. R., and Wong, K. K. (2012). Insulin-like growth factor: current concepts and new developments in cancer therapy. Recent Pat. Anticancer Drug Discov. 7, 14-30.

Kolb, E. A., Gorlick, R., Lock, R., Carol, H., Morton, C. L., Keir, S. T., et al. (2011). Initial testing (stage 1) of the IGF-1 receptor inhibitor BMS- 754807 by the pediatric preclinical testing program. Pediatr. Blood Cancer 56, 595-603.

Kolb, E. A., Kamara, D., Zhang, W., Lin, J., Hingorani, P., Baker, L., et al. (2010). R1507, a fully human monoclonal antibody targeting IGF-1R, is effective alone and in combination with rapamycin in inhibiting growth of osteosarcoma xenografts. Pediatr. Blood Cancer 55, 67-75.

Kurzrock, R., Patnaik, A., Aisner, J., Warren, T., Leong, S., Benjamin, R., et al. (2010). A phase I study of weekly R1507, a human monoclonal antibody insulin-like growth factor-I receptor antagonist, in patients with advanced solid tumors. Clin. Cancer Res. 16, 2458-2465.

Lacy, M. Q., Alsina, M., Fonseca, R., Paccagnella, M. L., Melvin, C. L., Yin, D., et al. (2008). Phase I, pharmacokinetic and pharmacodynamic study of the anti-insulinlike growth factor type 1 receptor monoclonal antibody CP-751,871 in patients with multiple myeloma. J. Clin. Oncol. 26, 3196-3203.

Litzenburger, B. C., Creighton, C. J., Tsimelzon, A., Chan, B. T., Hilsenbeck, S. G., Wang, T., et al. (2011). High IGF-IR activity in triple-negative breast cancer cell lines and tumorgrafts correlates with sensitivity to anti-IGF-IR therapy. Clin. Cancer Res. 17, 2314-2327. 
Ma, J., Pollak, M. N., Giovannucci, E., Chan, J. M., Tao, Y., Hennekens, C. H., et al. (1999). Prospective study of colorectal cancer risk in men and plasma levels of insulin-like growth factor (IGF)-I and IGF-binding protein-3. J. Natl. Cancer Inst. 91, 620-625.

Major, J. M., Laughlin, G. A., Kritz-Silverstein, D., Wingard, D. L., and Barrett-Connor, E. (2010). Insulin-like growth factor-I and cancer mortality in older men. $J$. Clin. Endocrinol. Metab. 95, 1054 1059.

Mitsiades, C. S., Mitsiades, N. S., Mcmullan, C. J., Poulaki, V., Shringarpure, R., Akiyama, M., et al. (2004). Inhibition of the insulin-like growth factor receptor-1 tyrosine kinase activity as a therapeutic strategy for multiple myeloma, other hematologic malignancies, and solid tumors. Cancer Cell 5, 221-230.

Molife, L. R., Fong, P. C., Paccagnella, L., Reid, A. H., Shaw, H. M., Vidal, L., etal. (2010). The insulin-like growth factor-I receptor inhibitor figitumumab (CP-751,871) in combination with docetaxel in patients with advanced solid tumours: results of a phase Ib dose-escalation, openlabel study. Br. J. Cancer 103, 332-339.

Mulvihill, M. J., Cooke, A., RosenfeldFranklin, M., Buck, E., Foreman, K., Landfair, D., et al. (2009). Discovery of OSI-906: a selective and orally efficacious dual inhibitor of the IGF-1 receptor and insulin receptor. Future Med. Chem. 1, 1153-1171.

Naing, A., Lorusso, P., Fu, S., Hong, D. S., Anderson, P., Benjamin, R. S., et al. (2012). Insulin growth factorreceptor (IGF-1R) antibody cixutumumab combined with the mTOR inhibitor temsirolimus in patients with refractory Ewing's sarcoma family tumors. Clin. Cancer Res. 18, 2625-2631.

Olmos, D., Postel-Vinay, S., Molife, L. R., Okuno, S. H., Schuetze, S. M., Paccagnella, M. L., et al. (2010). Safety, pharmacokinetics, and preliminary activity of the anti-IGF-1R antibody figitumumab (CP-751,871) in patients with sarcoma and Ewing's sarcoma: a phase 1 expansion cohort study. Lancet Oncol. 11, 129-135.

Palmqvist, R., Hallmans, G., Rinaldi, S., Biessy, C., Stenling, R., Riboli, E., et al. (2002). Plasma insulin-like growth factor 1, insulin-like growth factor binding protein 3 , and risk of colorectal cancer: a prospective study in northern Sweden. Gut 50, 642-646.
Pandini, G., Frasca, F., Mineo, R., Sciacca, L., Vigneri, R., and Belfiore, A. (2002). Insulin/insulin-like growth factor I hybrid receptors have different biological characteristics depending on the insulin receptor isoform involved. J. Biol. Chem. 277, 39684 39695.

Pappo, A. S., Patel, S. R., Crowley, J., Reinke, D. K., Kuenkele, K. P. Chawla, S. P., et al. (2011). R1507, a monoclonal antibody to the insulinlike growth factor 1 receptor, in patients with recurrent or refractory Ewing sarcoma family of tumors: results of a phase II Sarcoma Alliance for Research through Collaboration study. J. Clin. Oncol. 29, 45414547.

Pitts, T. M., Tan, A. C., Kulikowski, G. N., Tentler, J. J., Brown, A. M., Flanigan, S. A., et al. (2010). Development of an integrated genomic classifier for a novel agent in colorectal cancer: approach to individualized therapy in early development. Clin. Cancer Res. 16, 3193-3204.

Pollak, M. (2008). Insulin and insulinlike growth factor signalling in neoplasia. Nat. Rev. Cancer 8 915-928.

Pollak, M. N., Schernhammer, E. S., and Hankinson, S. E. (2004). Insulin-like growth factors and neoplasia. Nat. Rev. Cancer 4, 505-518.

Quek, R., Wang, Q., Morgan, J. A., Shapiro, G. I., Butrynski, J. E., Ramaiya, N., etal. (2011). Combination mTOR and IGF-1R inhibition: phase I trial of everolimus and figitumumab in patients with advanced sarcomas and other solid tumors. Clin. Cancer Res. 17, 871-879.

Ramalingam, S. S., Spigel, D. R., Chen, D., Steins, M. B., Engelman, J. A., Schneider, C. P., et al. (2011). Randomized phase II study of erlotinib in combination with placebo or R1507, a monoclonal antibody to insulinlike growth factor-1 receptor, for advanced-stage non-small-cell lung cancer. J. Clin. Oncol. 29, 45744580 .

Reidy, D. L., Vakiani, E., Fakih, M. G., Saif, M. W., Hecht, J. R., GoodmanDavis, N., et al. (2010). Randomized, phase II study of the insulin-like growth factor-1 receptor inhibitor IMC-A12, with or without cetuximab, in patients with cetuximab- or panitumumab-refractory metastatic colorectal cancer. J. Clin. Oncol. 28, 4240-4246.

Reidy-Lagunes, D. L., Vakiani, E. Segal, M. F., Hollywood, E. M., Tang, L. H., Solit, D. B., et al. (2012). A phase 2 study of the insulin-like growth factor-1 receptor inhibitor MK-0646 in patients with metastatic, well-differentiated neuroendocrine tumors. Cancer 118, 4795-4800.

Renehan, A. G., Zwahlen, M., Minder, C., O'Dwyer, S. T., Shalet, S. M., and Egger, M. (2004). Insulin-like growth factor (IGF)-I, IGF binding protein3 , and cancer risk: systematic review and meta-regression analysis. Lancet 363, 1346-1353.

Rinaldi, S., Cleveland, R., Norat, T., Biessy, C., Rohrmann, S., Linseisen, J., et al. (2010). Serum levels of IGF-I, IGFBP-3 and colorectal cancer risk: results from the EPIC cohort, plus a meta-analysis of prospective studies. Int. J. Cancer 126, 1702 1715.

Rowinsky, E. K., Youssoufian, H., Tonra, J. R., Solomon, P., Burtrum, D., and Ludwig, D. L. (2007). IMC-A12, a human IgG1 monoclonal antibody to the insulin-like growth factor I receptor. Clin. Cancer Res. 13, 5549s$5555 \mathrm{~s}$

Sachdev, D., Hartell, J. S., Lee, A. V., Zhang, X., and Yee, D. (2004). A dominant negative type I insulinlike growth factor receptor inhibits metastasis of human cancer cells. $J$ Biol. Chem. 279, 5017-5024.

Scartozzi, M., Bianconi, M., Maccaroni, E., Giampieri, R., Berardi, R., and Cascinu, S. (2010). Dalotuzumab, a recombinant humanized $\mathrm{mAb}$ targeted against IGFR 1 for the treatment of cancer. Curr. Opin. Mol. Ther. 12, 361-371.

Schmitz, S., Kaminsky-Forrett, M. C., Henry, S., Zanetta, S., Geoffrois, L., Bompas, E., et al. (2012). Phase II study of figitumumab in patients with recurrent and/or metastatic squamous cell carcinoma of the head and neck: clinical activity and molecular response (GORTEC 2008-02). Ann. Oncol. 23, 2153-2161.

Scotlandi, K., Avnet, S., Benini, S., Manara, M. C., Serra, M., Cerisano, V., et al. (2002). Expression of an IGFI receptor dominant negative mutant induces apoptosis, inhibits tumorigenesis and enhances chemosensitivity in Ewing's sarcoma cells. Int. J. Cancer 101, 11-16.

Scotlandi, K., Manara, M. C., Nicoletti, G., Lollini, P. L., Lukas, S., Benini, S., et al. (2005). Antitumor activity of the insulin-like growth factor-I receptor kinase inhibitor NVP-AEW541 in musculoskeletal tumors. Cancer Res. 65, 3868-3876.

Sell, C., Dumenil, G., Deveaud, C., Miura, M., Coppola, D., Deangelis, T., et al. (1994). Effect of a null mutation of the insulin-like growth factor I receptor gene on growth and transformation of mouse embryo fibroblasts. Mol. Cell. Biol. 14, 3604-3612.

Stattin, P., Bylund, A., Rinaldi, S., Biessy, C., Dechaud, H., Stenman, U. H., et al. (2000). Plasma insulin-like growth factor-I, insulin-like growth factor-binding proteins, and prostate cancer risk: a prospective study. J. Natl. Cancer Inst. 92, 19101917.

Tanno, B., Mancini, C., Vitali, R., Mancuso, M., Mcdowell, H. P., Dominici, C., et al. (2006). Down-regulation of insulin-like growth factor I receptor activity by NVP-AEW541 has an antitumor effect on neuroblastoma cells in vitro and in vivo. Clin. Cancer Res. 12, 6772-6780.

Tap, W. D., Demetri, G., Barnette, P., Desai, J., Kavan, P., Tozer, R., et al. (2012). Phase II study of ganitumab, a fully human anti-type-1 insulinlike growth factor receptor antibody, in patients with metastatic Ewing family tumors or desmoplastic small round cell tumors. J. Clin. Oncol. 30, 1849-1856.

Tazzari, P. L., Tabellini, G., Bortul, R., Papa, V., Evangelisti, C., Grafone, T., etal. (2007). The insulin-like growth factor-I receptor kinase inhibitor NVP-AEW541 induces apoptosis in acute myeloid leukemia cells exhibiting autocrine insulin-like growth factor-I secretion. Leukemia 21, 886-896.

Tolcher, A. W., Sarantopoulos, J., Patnaik, A., Papadopoulos, K., Lin, C. C., Rodon, J., et al. (2009). Phase I, pharmacokinetic, and pharmacodynamic study of AMG 479, a fully human monoclonal antibody to insulin-like growth factor receptor 1. J. Clin. Oncol. 27, 58005807.

Urbanska, K., Trojanek, J., Del Valle, L., Eldeen, M. B., Hofmann, F., Garcia-Echeverria, C., et al. (2007). Inhibition of IGF-I receptor in anchorage-independence attenuates GSK-3beta constitutive phosphorylation and compromises growth and survival of medulloblastoma cell lines. Oncogene 26, 2308-2317.

Wan, X., Harkavy, B., Shen, N., Grohar, P., and Helman, L. J. (2007). Rapamycin induces feedback activation of Akt signaling through an IGF1R-dependent mechanism. Oncogene 26, 1932-1940.

Wang, Y., Hailey, J., Williams, D., Lipari, P., Malkowski, M., Wang, X., et al. (2005). Inhibition of insulin-like growth factor-I receptor (IGF-IR) signaling and tumor cell growth by a fully human neutralizing anti-IGF-IR 
antibody. Mol. Cancer Ther. 4, 1214 1221.

Warshamana-Greene, G. S., Litz, J., Buchdunger, E., Garcia-Echeverria, C., Hofmann, F., and Krystal, G. W. (2005). The insulin-like growth factor-I receptor kinase inhibitor, NVP-ADW742, sensitizes small cell lung cancer cell lines to the effects of chemotherapy. Clin. Cancer Res. 11, 1563-1571.

Wittman, M. D., Carboni, J. M., Yang, Z., Lee, F. Y., Antman, M., Attar, R., etal. (2009). Discovery of a 2,4-disubstituted pyrrolo[1,2-f][1,2,4] triazine inhibitor (BMS-754807) of insulin-like growth factor receptor
(IGF-1R) kinase in clinical development. J. Med. Chem. 52, 7360-7363.

Wojtalla, A., Salm, F., Christiansen, D. G., Cremona, T., Cwiek, P., Shalaby, T., etal. (2012). Novel agents targeting the IGF-1R/PI3K pathway impair cell proliferation and survival in subsets of medulloblastoma and neuroblastoma. PLoS ONE 7:e47109. doi: 10.1371/journal.pone.0047109

Wolk, A., Mantzoros, C. S., Andersson, S. O., Bergstrom, R., Signorello, L. B. Lagiou, P., et al. (1998). Insulin-like growth factor 1 and prostate cancer risk: a population-based, casecontrol study. J. Natl. Cancer Inst. 90, 911-915.
Zeng, X., Zhang, H., Oh, A., Zhang, Y., and Yee, D. (2012). Enhancement of doxorubicin cytotoxicity of human cancer cells by tyrosine kinase inhibition of insulin receptor and type I IGF receptor. Breast Cancer Res. Treat. $133,117-126$

Conflict of Interest Statement: The author declares that the research was conducted in the absence of any commercial or financial relationships that could be construed as a potential conflict of interest.

Received: 18 January 2013; accepted: 04 March 2013; published online: 22 March 2013.
Citation: Arcaro A (2013) Targeting the insulin-like growth factor-1 receptor in human cancer. Front. Pharmacol. 4:30. doi: 10.3389/fphar.2013.00030

This article was submitted to Frontiers in Pharmacology of Anti-Cancer Drugs, a specialty of Frontiers in Pharmacology.

Copyright (c) 2013 Arcaro. This is an openaccess article distributed under the terms of the Creative Commons Attribution License, which permits use, distribution and reproduction in other forums, provided the original authors and source are credited and subject to any copyright notices concerning any third-party graphics etc. 